\title{
READERS
}

Journal of Management Info (JMI)

ISSN:2313-3376

www.readersinsight.net/jmi

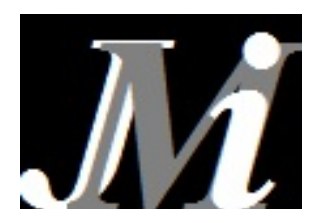

\section{War against terrorism and its impact on children's academic performance in district Swat Khyber Pakhtunkhwa Pakistan}

\author{
Muhammad Adnan Ali ${ }^{1}$, Nasim Khan Mahsud ${ }^{2}$, Waseem Khan ${ }^{3}$, Dr. Arab Naz ${ }^{4 *}$ \\ ${ }^{1}$ Department of Sociology, University of Malakand, Pakistan \\ ${ }^{2}$ Allama Iqbal Open University Islamabad Pakistan \\ ${ }^{3}$ University of Malakand, Pakistan \\ ${ }^{4}$ Department of Sociology and Social Work, University of Malakand, Khyber Pakhtunkhwa Pakistan \\ *Corresponding author: arab_naz@yahoo.com
}

\begin{abstract}
Terrorism has immensely affected the lives and standard of living of common masses across the country. Such a menace gave birth to numerous apprehensions and affected lives of subject masses and adversely impacted the institutions. The current study tends to investigate the impacts of war against terrorism/militancy on children's education, specifically on their academic performance in District Swat, Khyber Pakhtunkhwa, Pakistan. Data has been collected from 200 children of class 9th and 10th in the target area using stratified random sampling technique through interview schedule. Besides, the analysis has been performed through SPSS, using Chi-Square test where findings of the study show that militancy and terrorism have multiple and diverse impacts upon students' academic achievements and learning performance in the form of grading, marks' attainment, enrollment and behavior.
\end{abstract}

ARTICLE INFORMATION

\section{Received: 25 Jan 2016 \\ Revised: 25 March 2016 \\ Accepted: 25 March 2016}

DOI:

http://dx.doi.org//10.31580/jmi.v9i1.49

\section{Introduction}

The insurgency as a result of the fight against terrorism has greatly affected the life of civil population across the country (Hashmi, 2009). Huge number of atrocities and loss of lives has brought about enormous changes in general life pattern and basic institutions of the country, while security of the state and its institutions has been at risk for long time. This threat to internal security has weakened the social fabric at large and its outcome would affect the history of the country (Cheema, 2005). There are various approaches to define the term terrorism while the aspect of terrorism according to Whylie, (1967) is a form of violence used to create fear or gain a desired motive as well. Similarly, another aspect of terrorism is a war, which refers to the use of force or hostility through armed intervention i.e. particularly among nations or states or even two parties (Ryser, 2012). In the context of the current study, the term terrorism has been used as form of aggression producing fear among masses for the purpose of gaining some hidden or overt objectives with the inculcation of terror among the inhabitants (Garrison, 2010, Silver, 2010). Literature and other media sources have projected the issue throughout the globe and studies in the subject indicate that the use of weapons with producing terror has been utilized for mass destruction and even damaging the public places as well. In this context, Sara (2009) is of the opinion that a massive destruction has been caused by the use of weapons in shape of killing the innocents, devastation of the infrastructure such as bridges, dams, water channels, computer systems and more prominently the educational institution to a larger extent. Beside this, at some places, teachers and students have been jailed, threatened, and even in many places they are reported as murdered by the forces (Country Reports for Education, 2009).

Similarly, the study of Jenkins (2008) points to mass abduction, indoctrination of school children for suicide bombing and even tortured and abused by the forces. Further, reports on damaging educational infrastructure indicate that more than 250 schools were blown up in 2006 and 2007 (Gunaratna \& Iqbal, 2007). Several academic institutions have blown-up and hundreds of students were killed in by bomb blasts and various anti-human conflicts. In this regard, only in Iraq 71 academic institutes and several education officials and more than 30 students were killed during arm combat, while in Georgia almost 127 primary schools were damaged or destroyed in August 2008 (HRW, 2009).

The discussion above reflects that there is a strong antagonism of war with enlightenment and it is the most vulnerable aspect to be targeted that has affected the social life (Sara, 2009). The Global and regional scenario as noted by Jenkins (2008) also indicates that terrorism is pivotal problem, which create mass destruction, vulnerability and even killing of innocent people. The basic structure, functions and relation of different institutions within the social fabrics had to respond to the situation and change its course accordingly (Malik, 2009). Study of such changes and its impact on society is of critical importance as the evils of militancy are not only devastating the social fabric of the society but also damages the physical infrastructure of the country.

\section{Statement of the problem}


District Swat in particular and Malakand Division in general remained under a massive and severe wave of extremism, militancy and terrorism since 2008 (Zahid, 2008). While leaving the area in the hands of militants with almost no rule of law, resulted in the bloodshed and finally led to the second exodus of human's history where millions of the susceptible masses were internally displaced (ID) (Bari, 2009). Resultantly, Swat was disconnected from the rest of the world in terms of social, economic and physical relations for an extended period of time (Aftab, 2008). Furthermore, Khan (2009) argues that people in general and those in any association with the government were put on target, killed, harassed and threatened to death, while the situation worsened when militancy and terrorism expanded to other districts of the Malakand Division like Buner, Lower Dir and District Malakand (KPK Pakistan). Moreover, the government agencies in their pursuit of such elements launched a massive military operation. As a result of raising militancy and terrorism and military operation, approximately three million people from Malakand division were displaced to down districts of the province (Ali, 2010). However due to war on terrorism ' children's life had badly affected in terms of infrastructural destruction, wastage of time, delayed and broken academic session (Abbas, 2007). Moreover a sort of brain washing was reported among the Taliban ranks where they mold the mind of the innocents and sent them as suicide attackers (Daniel, 2008). During this conflict children not only felt pain from educational attainment but they also faced the threat of abduction or killing for supposedly getting secular education (Fair, 2007). After years still these traumatize children have no preventive measures from concerned authorities including governmental and non-governmental.

\section{Objectives of the study}

1. To analyze the impact of war on terror on students' academic performance

2. To highlight the impact of terrorism on students' behavioral and personality modification

\section{Hypotheses of the study}

H1: Peaceful environment improves students' academic performance and grade achievements

H2: War on terror has negative consequences upon behavior and personality development

\section{Methodology of the study}

This research study is an effort to explore war against terrorism and its impact on students' education in district Swat. The study qualifies both qualitative and quantitative nature where the primary (field study) and the secondary sources (literature review) are rationally utilized to acquire the facts. The study was conducted in Mingora city of District Swat, Khyber Pakhtunkhwa Pakistan, where the data has been collected from 4 secondary schools. In order to achieve the accurate and precise results, the data was collected from the students of $9^{\text {th }}$ and $10^{\text {th }}$ classes through interview schedule. A total of 740 respondents were selected using stratified random sampling technique whereas the researcher selected 200 respondents from the mentioned population. The responses of respondents were quoted on categorization as 'impact to some extent', 'impact to greater extent' and 'no impact', coded in the SPSS (Statistical Package for Social Science) with 1, 2 and 3 denoted as (TSE), (TGE) and (NI) accordingly. Data has been evaluated with the use of statistical test i.e. chi-square along-with correlation to verify the mentioned hypotheses for the purpose of generalization.

\section{Results and discussion}

The empirical data collected in person to person communication with the respondents is statistically analyzed and presented in technical research manner. In this regard, Table-1 demonstrates the impact of terrorism and war against terrorism on academic performance of the students.

\section{Impact of terrorism on academic performance of students}

The following data undeniably shows the numerous aspects, which are associated with students' knowledge about war against terrorism and its impact upon students' academics and career. The statistics of the data elucidate that academic performances improve to a greater extent through class participation and increasing level of attendance, grading and marks.

Table 1: Impact on students' academic performances
\begin{tabular}{|l|l|l|l|}
\hline $\begin{array}{l}\text { Impact upon } \\
\text { different levels }\end{array}$ & \multicolumn{2}{l|}{ Level and Extent of Impact } \\
\hline $\begin{array}{l}\text { Academic } \\
\text { performances }\end{array}$ & $\begin{array}{l}\text { To some } \\
\text { extent }\end{array}$ & $\begin{array}{l}\text { To greater } \\
\text { extent }\end{array}$ & No impact \\
\hline $\begin{array}{l}\text { Participation in } \\
\text { Class Lecture }\end{array}$ & $15 \%$ & $70 \%$ & $15 \%$ \\
\hline Class Attendance & $11 \%$ & $85 \%$ & $4 \%$ \\
\hline Grading in papers & $11 \%$ & $80 \%$ & $9 \%$ \\
\hline $\begin{array}{l}\text { Marks } \\
\text { Achievement }\end{array}$ & $5 \%$ & $85 \%$ & $10 \%$ \\
\hline $\begin{array}{l}\text { Decrease Learning } \\
\text { Capabilities }\end{array}$ & $10 \%$ & $80 \%$ & $10 \%$ \\
\hline Decrease Creativity & $13 \%$ & $70 \%$ & $17 \%$ \\
\hline
\end{tabular}

The value of chi-square for judging the association $\mathrm{P}=.001^{* *}<.05, \chi 2$ $=75.83$ while the D.f. $=9$ which confirms a significant relationship between students' perception regarding impact of war against terrorism and their academic performance. In addition, the factual data shows that students' knowledge about war against terrorism and its impact on learning and performance on students' academics is alluring and sustained the information to the degree that there is auspicious increase in less attainment of students in academic process. Furthermore, in report from the data which is conducted in the field illustrate that war against terrorism has greatly enlisted hesitancy and anxiety amid students that greatly affect their participation in class and decreases the capacity of learning among students. In addition, the statistics figured-out from mentioned table evidently display that students' confidence level, class lecture participation, class attendance and grading in papers are directly associated with a peaceful environment (View Table -1).

Therefore, knowledge of the students with regard to war against terrorism has close relation with academics and learning performance. The statistical test further verifies the results i.e. $\mathrm{P}=.001^{* * *}<.05$ which displays an association among students' knowledge about war against terrorism and its impact on their performances in relation to their academics, $\left(\chi^{2}=75.83\right.$, D.f. $\left.=9\right)$.

\begin{tabular}{|c|c|c|c|}
\hline & & Academic & $\begin{array}{l}\text { Students } \\
\text { knowledge } \\
\text { about } \\
\text { terrorism }\end{array}$ \\
\hline & & Performance & \\
\hline Academic & Pearson & 1 & $0.923^{\star \star}$ \\
\hline \multirow{3}{*}{ Performance } & Correlation & & \\
\hline & Sig. (2-tailed) & & .005 \\
\hline & $\mathrm{N}$ & 200 & 200 \\
\hline Students & Pearson & $.923^{* *}$ & 1 \\
\hline Knowledge & Correlation & & \\
\hline About terrorism & Sig. (2-tailed) & .000 & \\
\hline Size & $\mathrm{N}$ & 200 & 200 \\
\hline
\end{tabular}

$\left(^{* *}\right.$ Correlation is highly significant at the 0.01 level (2-tailed), $\mathrm{r}(200)=0.923^{* *}$; $\mathrm{p}<.01 . \mathrm{r}^{2}=0.92$ ) (Since $89 \%$ of the variance is shared which, shows that the association is strong in nature)

The association of the Correlation test further justify the results that i.e. ${ }^{* *}$ Correlation is significant on the level i.e. 0.01 (2-tailed), $\mathrm{r}(200)$ $=0.923^{* *} ; \mathrm{p}<.01 . \mathrm{r}^{2}=0.92$, since $89 \%$ of the variance is shared, the 
association remains strong. Similarly, the numerical values given for correlation (above) show a positive relationship between terrorism and its impact on children academic performance.

\section{Terrorism and students' behavioral and personality modification}

Behaviors and personality are the combination of emotions, attitude and impulses of a person (Angler, 2009). Different personality theorists had their own opinions regarding personality as Smith et al (2003) in the context of his thoughts regarding personality is the distinctive patterns of thoughts and emotion with behaviors that established a person as a unique entity of the society and to interact with others. Similarly, educational institutes are the systems which include a process to shape the personality and behavior of the students. Information through experiment of this study clarifies the association between war against terrorism and students' personality and behavior modifications. The experimental data explain that terrorism greatly affected students' behaviors and personality. The information evidently clarifies that terrorist activities in the area increases depression, anxiety, and reduces his participation to a greater extent which directly dominate and intensify students' behavior and defect in his personality. The statistical interpretation demonstrates that terrorist activities increases, anxiety and decrease students' vigor to a higher extent that damages students' input to society (view Table-2).

\begin{tabular}{|c|c|c|c|}
\hline \multirow{2}{*}{$\begin{array}{l}\text { Impact upon } \\
\text { different levels } \\
\text { Behavioral } \\
\text { modification and } \\
\text { personality } \\
\text { change }\end{array}$} & \multicolumn{3}{|c|}{ (n) } \\
\hline & $\begin{array}{l}\text { To some } \\
\text { amount }\end{array}$ & $\begin{array}{l}\text { To greater } \\
\text { amount }\end{array}$ & No impact \\
\hline $\begin{array}{l}\text { Increase in } \\
\text { Depression }\end{array}$ & $9 \%$ & $79 \%$ & $12 \%$ \\
\hline $\begin{array}{l}\text { Reduce Self- } \\
\text { Esteem }\end{array}$ & $20 \%$ & $76 \%$ & $4 \%$ \\
\hline $\begin{array}{l}\text { Decrease in } \\
\text { confidence level }\end{array}$ & $16 \%$ & $77 \%$ & $07 \%$ \\
\hline Increase in Anxiety & $7 \%$ & $82 \%$ & $9 \%$ \\
\hline $\begin{array}{l}\text { Increase } \\
\text { Aggressiveness }\end{array}$ & $11 \%$ & $74 \%$ & $15 \%$ \\
\hline Social isolation & $13 \%$ & $73 \%$ & $14 \%$ \\
\hline $\begin{array}{l}\text { Decrease } \\
\text { potentiality of the } \\
\text { students }\end{array}$ & $16 \%$ & $78 \%$ & $06 \%$ \\
\hline
\end{tabular}

$\left(\mathrm{P}=.003^{* *}<.05\right.$ there is high relation between terrorism and students behavior and modification and changes in personality trait i.e. $\left(X^{2}=\right.$ 55.79 , D.f. $=8$ )

With regard to the hypothetical statements given above i.e. Hypothesis-2 showing research purpose and connection of war on terror surely alter students' behaviors. The hypothesis was testified through the operation of chi-square test where the value of $\mathrm{P}=.003^{* *}<$ .05 , and such relations make it significantly associated with one another, which shows justified relation between variables with the value of $\chi^{2}=55.79$, D.f. $=8$. Similarly, the correlation test (given in the following table is another statistical analysis of the phenomena presented below:

\section{Correlation of terrorism, behavioral and personality modification of the students}

Change in change in

Personality behavior

\begin{tabular}{|l|l|l|l|}
\hline Personality & Pearson & 1 & $0.924^{* *}$ \\
\hline Change & Correlation & & \\
\hline & Sig. (2-tailed) & & .004 \\
\hline & N & 200 & 200 \\
\hline Behavioral & Pearson & $.924^{* *}$ & 1 \\
\hline Change & Correlation & & \\
\hline
\end{tabular}

\begin{tabular}{|l|l|l|l|}
\hline & Sig. (2-tailed) & .000 & \\
\hline & N & 200 & 200 \\
\hline
\end{tabular}

( ${ }^{* *}$ Correlation is highly significant at the 0.01 level (2-tailed), $r(200)$ $=0.982^{* *} ; p<.01 . r^{2}=0.98$ ) (Since $83 \%$ of the variance is shared, the association is obviously a strong one)

The tabular data with regard to correlation assert that results obtained in the form of ${ }^{* *}$ Correlation at 0.01 level (2-tailed), r (200) $=0.924^{* *}$; $\mathrm{p}<.01 . \mathrm{r}^{2}=0.92$ is significant and further, the information show that $83 \%$ of the variance is shared among the variable and its analysis. Thus, the data conform that such association is a strong one and the given hypothesis is valid.

\section{Discussion over results}

Investigation of the field data clarifies that war against terrorism is one of the issues in creating an atmosphere not suitable for the students and their academic performance. The information obtained from research respondents discloses the matter that war against terrorism creates aggressiveness, disturbs behavior that creates deviation among students and affects their attitude while increasing the level of isolation. Along-with this, most of the respondents were of the view that war against terrorism decreases sense of empathy among the students. Similarly, the results of the various indicators reflect that militancy and terrorism decreases harmony and sense of oneness that lead to "I" feelings, social isolation and further reduces social solidarity among the subject participants. The information regarding academic performance i.e. test scores, class participation and attendance, results and co-curricular activities are affected to a high extent. To sum-up the discussion, the association of militancy and terrorism with students' academic achievement has been tested through statistical tests confirming adverse effects on academics.

\section{Conclusion}

This study aimed at exploring the nature and extent of impact brought by terrorism to the local education institution. The collected information and its analyses present a transparent picture of the changed situation, which has resulted due to terrorism in the area (Swat). The research study thus concludes that terrorism has left the local education institutions in chaos. The impacts were short term though they added to the miseries of the local people already passing through turmoil. The findings reveal a direct impact on majority of the students' behavioral improvement and personality development process. The degree and nature of the negative impacts to the educational institutions varied, however an average number of students have same impacts. The argument to this conclusion is that in the changed situation with absence of peace and tranquility, the educational sector has gone through a tough time and is currently crossing through the stage of transition to achieve the desired and proposed status while combating the terroristic remains.

\section{Recommendations}

It has been recommended in the context of mentioned issue that there should be peace processes to reinstate the students' issues. In this regard, governmental and non-governmental sectors should play their roles in a precise manner. Furthermore, government should keep eye on the Madaris (religious educational institutions) and register these institutes that provide religious education to the poor.

Religious leaders can also play an effective role by interpreting Islam. In Pakistan the religious parties and sectarian organizations are using Islam for their political motives. If these religious leaders interpret Islam in the true sense, it will greatly help in decreasing sectarian violence and terrorism.

The government needs to improve their foreign policies because being ally of war on terror which suffer the social and economic sectors. Government should revise their foreign policies and should develop friendly relations with neighbors to avoid in upcoming eras. 


\section{References}

Arthur, G. (2010). Terrorism the Nature of its History: Criminal Justice Studies. A Critical Journal of Crime, Law and Society. Vol, 10 (3). P.p. 23-29.

Ali, A. (2010). Militancy and Socio-economic Problems: A Case Study of Pakistan, National Institute of Strategic studies (NIPS), Islamabad.

Angler, B. (2009). Personality Theories: Eighth Edition. Belmont, CA: Wadsworth, Cenage Learning.

Abbas, H. (2011). Militancy in Pakistan Borderlands: Implications for the Nations and For Afghan Policy, Century Foundation, USA

Bari, F. (2009). Perception and Impacts of Terrorism/Talibanization in Pakistan. Heinrich boll Stiftung Germany.

Cheema, A. (2005). A profile of poverty in Pakistan. Center for Research on Poverty, Connecticut, USA.

Fair, C.C. (2008). The Madrassah Challenge: Militancy and Religious Education in Pakistan. Washington D.C.: USIP.
HRW. (2009). Up in flames: Humanitarian Law Violations and Civilian Victims in the Conflict over South Ossetia (New York ).

Hashmi, A.S. (2009). Terrorism, Religious Radicalism and Violence, Perspective from Pakistan, Institute of Peace and Conflict Studies (IPCS) Islamabad.

Jenkins, B. M (2008). International Terrorism the Other World War: (Ed 2009). Cambridge University Press.

Khan. (2009). Crises Group Interview: Islamabad.

Marphy, R \& Ziedy, M. (2009). Prisoners of war: A Comparative Study of Principles of International Humanitarian Law and the Islamic Law of War. ICLR 9 (1).

Ryser. (2012). Indigenous Nation and the Modern Stat: New York.

Sara, A. C. (2009). "Taliban Buying Children for Suicide Bombers" Washington Times.

Zahid, H. (2008). "Islamic Militants to Blow up Girls School If they Refuse to Close". The Times.

Zaidi, M. (2011). The Radicalization Process, the Daily Dawn, Feb 07. 